\title{
CHO/hPEPT1 Cells Overexpressing the Human Peptide Transporter (hPEPT1) as an Alternative in Vitro Model for Peptidomimetic Drugs
}

\author{
Hyo-kyung Han, ${ }^{\dagger}$ Julie K. Rhie, ${ }^{\dagger} \neq$ Doo-Man OH, ${ }^{\dagger}$ Go Salto,${ }^{\dagger}$ Cheng-Pang Hsu, ${ }^{\dagger}$ Barbra H. Stewart,${ }^{\S}$ and \\ GORDON L. AMIDON*,
}

Contribution from College of Pharmacy, The University of Michigan, Ann Arbor, Michigan 48109-1065, and Pharmacokinetics and Drug Metabolism Department, Parke-Davis Pharmaceutical Research, Division of Warner-Lambert Company,

Ann Arbor, Michigan 48105.

Received March 19, $1998 . \quad$ Final revised manuscript received December 8, 1998.

Accepted for publication December 9, 1998.

\begin{abstract}
The present study characterized Chinese hamster ovary cells overexpressing a human intestinal peptide transporter, $\mathrm{CHO} /$ hPEPT1 cells, as an in vitro model for peptidomimetic drugs. The kinetic parameters of Gly-Sar uptake were determined in three different cell culture systems such as untransfected $\mathrm{CHO}$ cells (CHO-K1), transfected $\mathrm{CHO}$ cells (CHO/hPEPT1) and Caco-2 cells. $V_{\max }$ in $\mathrm{CHO} /$ hPEPT1 cells was approximately 3 -fold higher than those in Caco-2 cells and $\mathrm{CHO}-\mathrm{K} 1$ cells, while $K_{\mathrm{m}}$ values were similar in all cases. The uptake of $\beta$-lactam antibiotics in CHO/hPEPT1 cells was three to twelve fold higher than that in $\mathrm{CHO}-\mathrm{K} 1$ cells, indicating that $\mathrm{CHO} /$ hPEPT1 cells significantly enhanced the peptide transport activity. However, amino acid drugs also exhibited high cellular uptake in both $\mathrm{CHO}-\mathrm{K} 1$ and $\mathrm{CHO} / \mathrm{hPEPT} 1$ cells due to the high background level of amino acid transporters. Thus, cellular uptake study in CHO/hPEPT1 cells is not sensitive enough to distinguish the peptidyl drugs from amino acid drugs. The potential of $\mathrm{CHO} / \mathrm{hPEPT} 1$ cells as an in vitro model for peptidomimetic drugs was also examined through the inhibition study on Gly-Sar uptake. Peptidomimetic drugs such as $\beta$-lactam antibiotics and enalapril significantly inhibited Gly-Sar uptake whereas the nonpeptidyl compounds, L-dopa and $\alpha$-methyldopa, did not compete with Gly-Sar for cellular uptake within the therapeutic concentrations. In conclusion, the present study demonstrates the further characterization of $\mathrm{CHO} / \mathrm{hPEPT} 1$ cells as an uptake model as well as inhibition study and suggests their utility as an alternative in vitro model for drug candidates targeting the hPEPT1 transporter.
\end{abstract}

\section{Introduction}

Since peptide transporters are potential targets for improving oral drug absorption through chemical modification due to the broad substrate specificity, ${ }^{1,2}$ an efficient screening tool is necessary for rapid evaluation of peptidyl drug candidates arising from rational drug design.

The advantages of in vitro cell cultures over conventional techniques have been summarized by Audus et al., ${ }^{3}$ which include (a) rapid evaluation of the permeability and metabolism of a drug, (b) the opportunity to characterize the molecular mechanism(s) of drug absorption /or drug metabolism, (c) rapid evaluation of strategies for enhancing drug absorption and minimizing drug metabolism, (d) the opportunity to use human cells, rather than animal tissues, and (e) the opportunity to minimize time-consuming,

\footnotetext{
* To whom correspondence should be addressed. E-mail: glamidon@ umich.edu, Phone: 734-764-2440, F ax: 734-763-6423.

+ University of Michigan.

₹ Present address: NIH-NIGMS/FDA-CBER-DCGT, Bethesda, Maryland 20892.

$\S$ Parke-Davis Pharmaceutical Research.
}

expensive, and sometimes controversial animal studies. Therefore, mammalian cell cultures are increasingly attractive to pharmaceutical scientists as a suitable in vitro model for drug transport and metabolism studies.

Caco-2 cells are well-characterized ${ }^{4}$ and currently the most widely used in vitro cell culture system for intestinal drug transport studies. However, this cell line exhibits various transport systems other than peptide transporters, 5,6 and it may be difficult to distinguish the responsible transport system for the test compound. In addition, the expression level of peptide transporters in Caco-2 cells is low, variable, and rather insufficient for the screening of peptidyl drug candidates. ${ }^{7}$ The advances in the cloning of peptide transporters and recombinant DNA technology have recently triggered several attempts to devel op a cell culture model having enhanced peptide transport activity. ${ }^{8-14}$ For instance, a human intestinal peptide transporter, hPEPT1, has been functionally expressed in $\mathrm{HeLa}$ cells ${ }^{13}$ and also stably transfected into the $\mathrm{CHO}$ cells. ${ }^{14}$ These overexpression systems provide the analytical advantage in verifying possible drug candidates with transport activity mediated via hPEPT1 transporter. Since the stable transfected cell line, CHO/hPEPT1 has been characterized only through inhibition studies using some peptidyl compounds, ${ }^{14}$ further characterization is necessary for its wide application as a screening tool of peptidomimetic drugs.

In the present study, the functional expression level of hPEPT 1 transporter in CHO/hPEPT 1 cells was evaluated by the kinetic study of Gly-Sar uptake and compared with those in untransfected $\mathrm{CHO}$ cells $(\mathrm{CHO}-\mathrm{K} 1)$ and $\mathrm{Caco}-2$ cells. The potential of CHO/hPEPT1 cells as a screening tool was examined through the uptake and the inhibition studies using both peptidyl and nonpeptidyl compounds as substrates of the hPEPT 1 transporter.

\section{Experimental Section}

Materials-Glycyl-[ $\left[{ }^{3} \mathrm{H}\right]$-sarcosine (specific radioactivity, 400 $\mathrm{mCi} / \mathrm{mmol}$ ) was purchased from Moravek Biochemicals I nc. (Brea, CA). Cephal exin, cephradine, cefaclor, ampicillin, enalapril, glycylsarcosine, L-dopa, and $\alpha$-methyldopa were purchased from Sigma Chemical Co. (St. Louis, MO). All tissue culture reagents were obtained from Gibco (Grand Island, NY). Other chemicals were either analytical or HPLC grade.

Cell Cultures-CHO/hPEPT1 cells were cultured in F-12 nutrition mixture (HAM) containing $10 \%$ fetal bovine serum (FBS), penicillin $(100 \mathrm{U} / \mathrm{ml}) /$ streptomycin $(100 \mathrm{mg} / \mathrm{mL})$, and $200 \mathrm{mg} / \mathrm{mL}$ G418. CHO-K 1 cells were cultured in the same media without G418. Caco-2 cells were routinely maintained in Dulbecco's modified Eagle's medium (DMEM) containing 10\% FBS, 1\% nonessential amino acids, $1 \mathrm{mM}$ sodium pyruvate, 1\% L-glutamine, and penicillin $(100 \mathrm{U} / \mathrm{ml}) /$ streptomycin $(100 \mathrm{mg} / \mathrm{mL})$. All cells were 
maintained in an atmosphere of $5 \% \mathrm{CO}_{2}$ and $90 \%$ relative humidity at $37^{\circ} \mathrm{C}$.

Kinetic Study of Gly-Sar Uptake in the Different Cell Culture Systems-CHO/hPEPT1 cells were seeded in 12-well culture plates at a density of $10^{5} \mathrm{cell} \mathrm{s} / \mathrm{cm}^{2}$. At 2 days postseeding, the cells were washed twice with $\mathrm{pH} 6.0$ uptake buffer containing $1 \mathrm{mM} \mathrm{CaCl}_{2}, 1 \mathrm{mM} \mathrm{MgCl}_{2}, 150 \mathrm{mM} \mathrm{NaCl}, 3 \mathrm{mM} \mathrm{KCl}, 1 \mathrm{mM} \mathrm{NaH}_{2^{-}}$ $\mathrm{PO}_{4}, 5 \mathrm{mM}$ D-glucose, and $5 \mathrm{mM}$ MES. Gly-Sar solution was prepared at seven different concentrations $(0.01 \mathrm{mM}$ to $50 \mathrm{mM}$, $0.4 \mu \mathrm{Ci} / \mathrm{mL}$ ). Each drug solution was added to each well and incubated at $25^{\circ} \mathrm{C}$. At each time point, cells were washed with ice-cold pH 6.0 uptake buffer three times to stop the cellular uptake. One milliliter of $1.5 \%$ ice-cold Triton $\mathrm{X}$ solution was added to each well and incubated for $30 \mathrm{~min}$ at $25^{\circ} \mathrm{C}$. Cells were harvested and transferred into vials containing $4 \mathrm{~mL}$ of the scintillation cocktail. Samples were analyzed by a scintillation counter, and the protein amount of each sample was measured by the method of Lowry et al. ${ }^{15}$ Kinetic parameters of Gly-Sar uptake were also determined in $\mathrm{CHO}-\mathrm{KI}$ cells and Caco-2 cells following the same protocol as was performed in CHO/hPEPT1 cells.

Uptake Study in Both Untransfected and Transfected CHO Cells. Cells were seeded in six-well culture plates $\left(9.6 \mathrm{~cm}^{2}\right.$, growth area) at a density of $10^{5} \mathrm{cell} / \mathrm{s} / \mathrm{cm}^{2}$. At 2 days postseeding, the medium was removed and cells were washed twice with $\mathrm{pH}$ 6.0 uptake buffer. Independent studies were performed for each drug solution at $1 \mathrm{mg} / \mathrm{mL}$ made in $\mathrm{pH} 6.0$ uptake buffer. At each time point (10, 20,30,45, 60, $90 \mathrm{~min})$, drug solution was removed and cells were washed three times with ice-cold pH 6.0 uptake buffer. One milliliter of Milli-Q water was added to each well and incubated for $30 \mathrm{~min}$ at $25^{\circ} \mathrm{C}$. Cells were harvested and sonicated for 1-2 min. $\mathrm{ZnSO}_{4}$ solution $(8 \%, 200 \mathrm{~mL})$ was added to the cell lysate, vortexed rigorously, and centrifuged for $5 \mathrm{~min}$ at $3000 \mathrm{rpm}$. After filtration of the supernatant through a membrane filter $(0.45$ $\mathrm{mm})$, samples were analyzed by HPLC. The protein amount of each sample was determined by the method of Lowry et al..$^{15}$

Inhibition of Gly-Sar Uptake in CHO/hPE PT1 Cells. Cells were seeded in 12-well culture plates at a density of $10^{5} \mathrm{cell} / \mathrm{s} / \mathrm{cm}^{2}$. At 2 days postseeding, the cells were washed twice with $\mathrm{pH} 6.0$ uptake buffer. Each inhibitor solution (0.01 $\mathrm{mM}$ to $50 \mathrm{mM}$ ) containing ${ }^{3} \mathrm{H}$-Gly-Sar $(20 \mathrm{mM}, 0.4 \mu \mathrm{Ci} / \mathrm{ml})$ was added to each well and incubated for $30 \mathrm{~min}$ at $25^{\circ} \mathrm{C}$. After removing the drug solution, the cells were washed with ice-cold pH 6.0 uptake buffer three times to stop the cellular uptake. One milliliter of $1.5 \%$ icecold Triton $X$ solution was added to each well and incubated for $30 \mathrm{~min}$ at $25^{\circ} \mathrm{C}$. Cells were harvested and transferred into vials containing $4 \mathrm{~mL}$ of scintillation cocktail. Samples were analyzed by a scintillation counter (Beckman instruments Inc., Model LS9000), and the protein amount of each sample was measured by the method of Lowry et al.15

HPLC Assay-The instrument consists of a pump (Waters, Model 510, Milford, MA) and automatic sampler (Model 712 WISP Waters) and an UV detector (Waters, 990 Photodiode Array Detector, Milford, MA). Data acquisition and integration was carried out using the Millennium software. All compounds were separated on a reversed phase C-18 column (Beckman Ultrasphere, $5 \mu \mathrm{m}, 4.6 \times 250 \mathrm{~mm}$ ) under the conditions published by Walter et al. ${ }^{16}$

Data Analysis-Estimate of $I C_{50}-I n$ this study, $I C_{50}$ is defined as the drug concentration to show the $50 \%$ inhibition of Gly-Sar uptake. As described by De Lean et al., 17 it was determined from nonlinear regression of dose-response curve by the Sigma Plot program ( andel Scientific, San Rafael, CA) using the equation $f$ $=(a-d) /\left(1+(x / c)^{b}\right)+d$, where $a$ and $d$ represent the maximum and minimum uptake, respectively, $\mathrm{x}$ is the inhibitor concentration, and $b$ is the slope factor.

Determination of $\mathbf{K}_{\mathbf{m}}$ and $\mathbf{V}_{\mathbf{m a x}}-K_{m}$ and $V_{\max }$ for the uptake of each drug was determined by the nonlinear regression of $\mathrm{V}=$ $\mathrm{V}_{\max } \cdot \mathrm{C} /\left(\mathrm{K}_{\mathrm{m}}+\mathrm{C}\right)+\mathrm{K}_{\mathrm{d}} \mathrm{C}$, where $\mathrm{K}_{\mathrm{d}} \mathrm{C}$ represents a diffusional uptake rate

Statistical differences between two means were evaluated using a t-test assuming unequal variance.

\section{Results and Discussion}

Uptake Kinetics of Gly-Sar in the Different Cell Culture Systems-Due to the broad substrate specificity

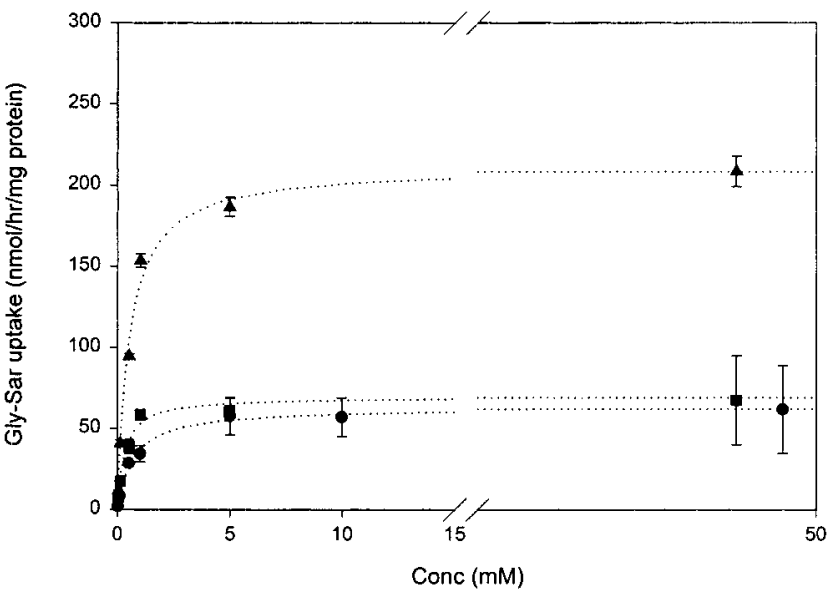

Figure 1-Kinetic study of Gly-Sar uptake in the different cell culture systems

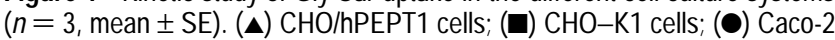
cells.

Table 1-Kinetic Parameters of Gly-Sar Uptake in Three Different Cell Lines $(n=3$, mean \pm SE)

\begin{tabular}{lcrr}
\hline & CHO/hPEPT1 & CHO-K1 & \multicolumn{1}{c}{ Caco-2 } \\
\hline$K_{\mathrm{m}}(\mathrm{mM})$ & $0.5 \pm 0.1$ & $0.3 \pm 0.1$ & $0.7 \pm 0.1$ \\
$V_{\max }$ & $211.2 \pm 16.4$ & $69.5 \pm 6.4$ & $62.5 \pm 2.9$ \\
$(\mathrm{nmol} / \mathrm{h} / \mathrm{mg}$ protein) & $1.8 \pm 0.4$ & $7.7 \pm 0.2$ & $5.5 \pm 0.1$ \\
$K_{\mathrm{d}}$ & & & \\
$(\mathrm{nmol} / \mathrm{h} / \mathrm{mg} \mathrm{protein} / \mathrm{mM})$ & & &
\end{tabular}

of the peptide transporter, a wide range of structurally unrelated molecules have exhibited significant binding affinity and are transported by the peptide transporter. ${ }^{18-21}$ Therefore, chemical modification targeting a peptide transporter to improve oral drug absorption is increasingly attractive to the pharmaceutical scientists. Thus, an efficient and rapid screening tool is needed to support the drug discovery process targeting the peptide transporters. The present study quatitatively evaluated the enhancement of peptide transport activity in CHO/hPEPT1 cells through the kinetic study of Gly-Sar uptake. Kinetic parameters of Gly-Sar uptake were determined in $\mathrm{CHO} /$ hPEPT1 cells and compared with those in untransfected $\mathrm{CHO}$ cells and Caco-2 cells which is the most prevalent in vitro cell culture system for intestinal drug absorption (Figure 1). As summarized in Table $1 . K_{m}$ values for GlySar uptake are similar in all three systems, which are comparable to those in other literatures. ${ }^{11,22} \mathrm{~V}_{\max } / \mathrm{K}_{\mathrm{m}}$ was 380 for $\mathrm{CHO} / \mathrm{hPEPT} 1$ cells, which is 2 -fold higher than that for $\mathrm{CHO}-\mathrm{K} 1$ cells and four times higher than that for Caco-2 cells. Compared with $\mathrm{K}_{d}$ that indicates the contribution of passive diffusion, $\mathrm{V}_{\max } / \mathrm{K}_{\mathrm{m}}$ was approximately 210 fold, 24-fold, and 17-fold higher in CHO/hPEPT1 cells, $\mathrm{CHO}-\mathrm{K} 1$ cells and Caco-2 cells, respectively, indicating that Gly-Sar uptake was predominantly carrier-mediated. Furthermore, as shown in Eadie-H ofstee plot (Figure 2), the cellular uptake of Gly-Sar appeared to be mediated by a single transporter, even though there are more than one peptide transporters in CHO/hPEPT1 cells (i.e., hPEPT1 and endogenous peptide transporter) and Caco-2 cells (i.e., PEPT1 and HPT1). This is probably due to the wide overlap of the substrate specificity among peptide transporters and consequently similar affinity of Gly-Sar to each peptide transporter. Taken all together, the Gly-Sar kinetic study indicated that CHO/hPEPT1 cells significantly enhanced the capacity of the peptide transport system while retaining the substrate specificity and that this system may be useful as an in vitro model for the rapid screening of peptidyl drugs. 


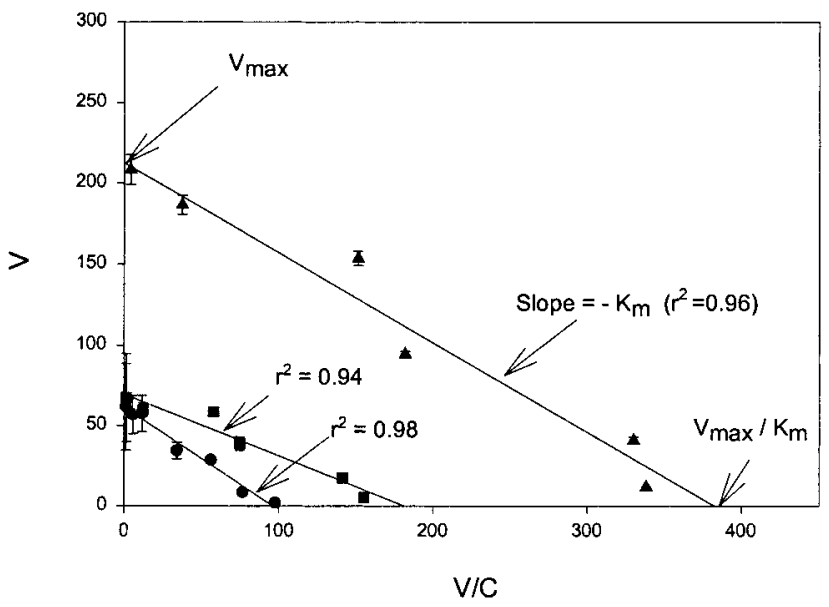

Figure 2-The Eadie-Hofstee plot of Gly-Sar uptake in the different cell culture systems $(n=3$, mean $\pm \mathrm{SE})$. $V$ and $C$ represent the uptake rate $(\mathrm{nmol} / \mathrm{h} / \mathrm{mg}$ protein) and Gly-Sar concentration (mM), respectively. ( $\mathbf{\Delta}) \mathrm{CHO} / \mathrm{hPEPT} 1$ cells; (ロ) CHO-K1 cells; (๑) Caco-2 cells.

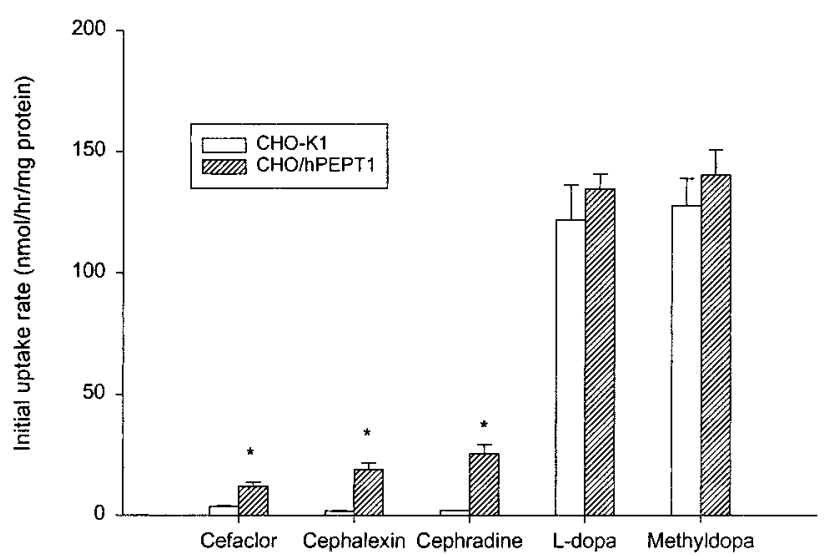

Figure 3-Cellular uptake of peptidyl and nonpeptidyl drugs in CHO/hPEPT1 cells (hatched bars) and in $\mathrm{CHO}-\mathrm{K} 1$ cells (open bars) $(n=3$, mean $\pm \mathrm{SE}$ ). $\left(^{*}\right)$ indicates $p<0.01$.

Uptake Studies in Both Transfected and Untransfected CHO Cells-The validity of CHO/hPEPT1 cells as an uptake model was examined using nonpeptidyl drugs as well as peptidyl compounds. Cellular uptake of $\beta$-lactam antibiotics was evaluated in CHO/hPEPT1 cells and compared with that in $\mathrm{CHO}-\mathrm{K} 1$ cells. Initial uptake rate of each drug was determined from the linearity of time versus uptake curve. Estimated uptake ratio between $\mathrm{CHO} /$ hPEPT 1 cells and $\mathrm{CHO}-\mathrm{K} 1$ cells (uptake rate CHO/hPEPTI/ $_{1}$ uptake rate ${ }_{\mathrm{CHO}-\mathrm{K} 1}$ ) was 3.3 for cefaclor, 10.3 for cephal exin, and 12.1 for cephradine (Figure 3 ). The cellular uptake of $\beta$-lactam antibiotics was significantly $(p<0.01)$ increased in $\mathrm{CHO} / \mathrm{hPEPT} 1$ cells compared with that in $\mathrm{CHO}-\mathrm{K} 1$ cells. These results demonstrated that $\mathrm{CHO} / \mathrm{hPEPT} 1$ cells greatly enhanced peptide transport activity via the transfection of hPEPTI gene.

The cellular uptake of L-dopa and $\alpha$-methyldopa which are known to be substrates of amino acid transporters 23,24 was also evaluated in both $\mathrm{CHO} / \mathrm{hPEPT} 1$ cells and $\mathrm{CHO}-$ $\mathrm{K} 1$ cells. As shown in Figure 3, amino acid analogues, L-dopa and $\alpha$-methyldopa, showed significant cellular uptake in both $\mathrm{CHO}-\mathrm{K} 1$ cells and $\mathrm{CHO} / \mathrm{hPEPT} 1$ cells which were even higher than $\beta$-lactam antibiotics. These results implicated that $\mathrm{CHO} / \mathrm{hPEPT} 1$ cells expressed a high background level of the amino acid transport system which is inherited from the native $\mathrm{CHO}$ cells. This explanation is also supported by other report that $\mathrm{CHO}$ cells exhibited some amino acid transport systems such as system A, ASC, and $L .{ }^{25} \mathrm{~F}$ or clarification, the expression level of amino acid

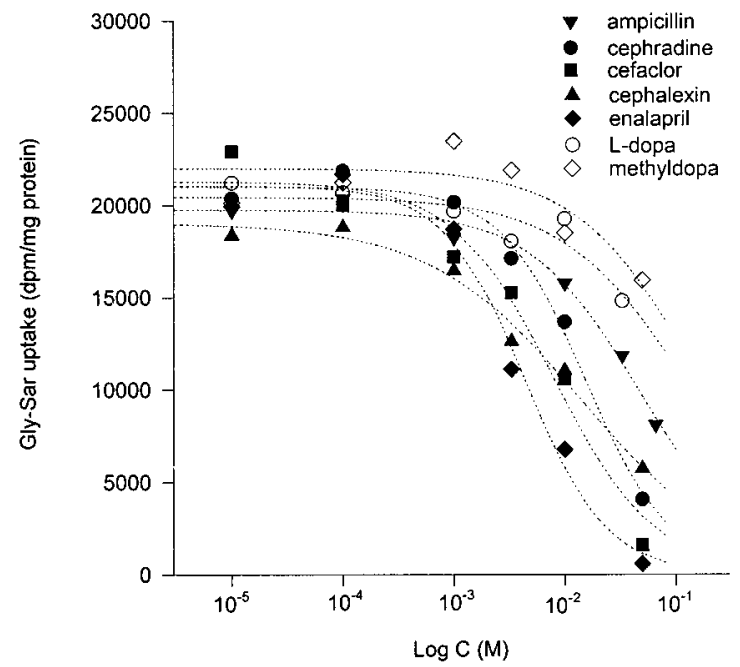

Figure 4-Inhibition of Gly-Sar uptake in CHO/hPEPT1 cells (mean $\pm \mathrm{SE}$ ): two independent studies were done for each inhibitor and every independent study had $n=3$. $\log C$ represents the inhibitor concentration.

Table 2-Inhibition Effect of Peptidomimetic Drugs on Gly-Sar Uptake in CHO/hPEPT1 Cells

\begin{tabular}{lc}
\hline & $\mathrm{IC}_{50}(\mathrm{mM})^{\mathrm{a}}$ \\
\hline Gly-Sar & $0.7 \pm 0.1$ \\
enalapril & $4.5 \pm 0.7$ \\
cefaclor & $8.2 \pm 1.8$ \\
cephalexin & $13.7 \pm 3.0$ \\
cephradine & $15.3 \pm 2.4$ \\
ampicillin & $47.4 \pm 6.0$ \\
L-dopa & $141.2 \pm 40.4$ \\
methyldopa & $151.6 \pm 21.4$
\end{tabular}
${ }^{a}{ }^{I} C_{50}$ was determined from two independent studies, and each study has
$n=3$, mean \pm SE.

transporters in CHO/hPEPT1 cells should be further evaluated by using antibodies specific for these transporters. Collectively, due to the high expression of amino acid transporters, uptake study al one in CHO/hPEPT1 cells is insufficient for screening peptidomimetic drug candidates.

Inhibition of Gly-Sar Uptake in CHO/hPEPT1 Cells-The potential of CHO/hPEPT1 cells as a rapid screening tool for peptidyl drug candidates was further examined through inhibition studies using peptidomimetic drugs (e.g., $\beta$-lactam antibiotics, enalapril) as well as nonpeptidyl drugs such as L-dopa and $\alpha$-methyldopa (Figure 4). $I C_{50}$ was determined as the drug concentration to demonstrate $50 \%$ inhibition of Gly-Sar uptake and summarized in Table 2. While L-dopa and $\alpha$-methyldopa did not inhibit Gly-Sar uptake within the therapeutic concentrations, $\beta$-lactam antibiotics and enalapril exhibited significant inhibition of Gly-Sar uptake (low IC $C_{50}$ ), implying that Gly-Sar and the peptidyl derivatives share the same peptide transport system for cellular uptake. Lower I $C_{50}$ indicates higher binding affinity to the peptide transporter, and thus enhancement of peptide transporter-mediated absorption is expected from lower $\mathrm{IC}_{50}$ values. Carriermediated permeability values $\left(\mathrm{P}_{\mathrm{C}}{ }^{*}\right)$ of $\beta$-lactam antibiotics and enal april from our previous studies ${ }^{26-28}$ were compared with inhibition effects on the peptide transporter (Figure 5). As shown in Figure $5, I C_{50}$ values of peptidomimetic drugs were reciprocally correlated to the intestinal permeability in rats $\left(r^{2}=0.91, p<0.05\right)$. These results suggest that inhibition studies on Gly-Sar uptake in CHO/hPEPT1 cells may rapidly elucidate the ability of a drug to interact with the hPEPT1 transporter.

Generally speaking, inhibition studies are not al ways a good predictor for the actual cellular uptake of drug candidates, since binding to a transporter does not neces- 


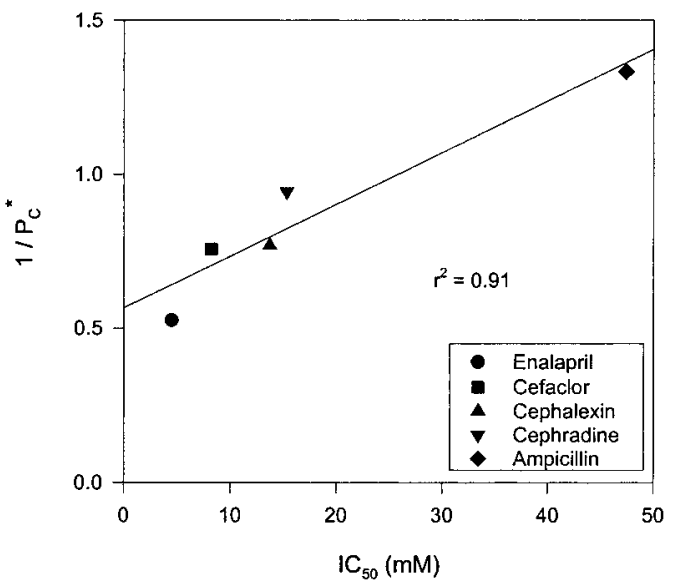

Figure 5-Correlation between $\mathrm{IC}_{50}$ in $\mathrm{CHO} / \mathrm{hPEPT} 1$ cells and the intestinal permeability in rats: $P_{\mathrm{c}}{ }^{*}$ represents the dimensionless carrier-mediated permeability in rats. Permeability data were selected from refs $25-27$.

sarily guarantee drug transport into cells. However, false positives may do little harm in the discovery of drug candidates for oral administration, since they can be excluded by further evaluation. Therefore, competitive inhibition studies in CHO/hPEPT1 cells as well as Caco-2 cells could be used for the initial screening of promising candidates from the various drug derivatives, and then more rigorous studies are necessary for further screening of drug candidates.

In conclusion, our present study can be summarized as follows. First, CHO/hPEPT1 cells significantly enhanced peptide transport activity via overexpression of hPEPT1 gene. Second, due to the high background level of amino acid transporters, the cellular uptake study al one in $\mathrm{CHO} /$ hPEPT 1 cells is insufficient for the screening of peptidyl drugs. Third, inhibition study in CHO/hPEPT1 cells can be served as an alternative in vitro model to support the drug discovery process targeting the peptide transporter.

\section{References and Notes}

1. Walter, E.; Kissel, T.; Amidon, G. L. The intestinal peptide carrier: A potential transport system for small peptide derived drugs. Adv. Drug Del. Rev. 1996, 20, 33-58.

2. Bai, J. P. F.; Stewart, B. H.; Amidon, G. L. Gastrointestinal Transport of Peptide and Protein Drugs and Prodrugs, Handbk. Exp. Pharmacol. 1994, 110, 189-206.

3. Audus, K. L.; Bartel, R. L.; Hidalgo, I. J .; Borchardt, R. T. The use of cultured epithelial and endothelial cells for drug transport and metabolism studies. Pharm. Res. 1990, 7, 435449.

4. Hidalgo, I.J .; Raub, T.J .; Borchardt, R. T. Characterization of the Human Colon Carcinoma Cell Line(Caco-2) as a Mode System for Intestinal E pithelial Permeability. Gastroenterology 1989, 96, 736-749.

5. Tamai, I.; Takanaga, H.; Maeda, H.; Sai, Y.; Ogihara, T. Higashida, H.; Tsuji, A. Participation of a proton-cotransporter, MCT1, in the intestinal transport of monocarboxylic acids. Biochem. Biophys. Res. Commun. 1995, 214, 482-489.

6. Mesonero, J.; Matosin, M.; Cambier, D.; Rodriguez-Y oldi, M. J .; Brot-Laroche, E.; Sugar-dependent expression of the fructose transporter GLUT5 in Caco-2 cells. Biochem. J. 1995, 312, 757-762

7. Chong, S.; Dando, S. A.; Soucek, K. M.; Morrison, R. A. In vitro permeability through Caco-2 cells is not quantitatively predictive of in vivo absorption for peptide-like drugs absorbed via the dipeptide transporter system. Pharm. Res. 1996, 13, 120-123.

8. Fei, Y.J .; Kanai, Y.; Nussberger, S.; Ganapathy, V.; Leibach, F. H.; Romero, M. F.; Singh, S. K.; Boron, W. F.; Hediger, M. A. Expression cloning of a mammalian protein-coupled oligopeptide transporter. Nature 1994, 386, 563-566.

9. Liu, W.; Ramamoorthy, S.; Fei, Y. J.; Ganapathy, N. E.; Hediger, M. A.; Ganapathy, V.; Leibach, F. H. Molecular cloning of PEPT2, a new member of the $\mathrm{H}^{+}$/peptide cotransporter family from human kidney. Biochim. Biophys. Acta. 1995, 1235, 461-466.

350 / Journal of Pharmaceutical Sciences Vol. 88, No. 3, March 1999
10. Dantzig, A. H.; Hoskins, J .; Tabas, L. B.; Bright, S.; Shepard, R. L.; J enkins, I. L.; Duckworth, D. C.; Sportsman, J. R.; Mackensen, D.: Rosteck P. R., r.: Skatrud, P. L. Association of intestinal peptide transport with a protein related to the cadherin superfamily, Science 1994, 264, 430-433.

11. Liang, R.; Fei, Y.J .; Prasad, P. D.; Ramamoorthy, S.; Han H.; Yang-Feng, T. L.; Hediger, M. A.; Ganapathy, V.; Leibach, F. H. Human intestinal $\mathrm{H}^{+}$/peptide cotransporter: cloning, functional expression and chromosomal localization J . Biol. Chem. 1995, 270, 6456-6463.

12. Terada, T.; Saito, H.; Mukai, M.; Inui, K. Characterization of stably transfected kidney epithelial cell line expressing rat $\mathrm{H}+/$ Peptide cotransporter PEPT1: localizaion of PEPT1 and transport of beta-lactam antibiotics. J . Pharmacol. Exp. Ther. 1997, 281, 1415-1421.

13. Ganapathy, M. E.; Brandsch, M.; Prasad, P. D.; Ganapathy, V.; Leibach, F. H. Differential recognition of $\beta$-lactam antibiotics by intestinal and renal peptide transporters, PEPT 1 and PEPT 2. J . Biol. Chem. 1995, 270, 25672-25677.

14. Covitz, K. Y., Amidon, G. L. Sadee, W. Human dipeptide transporter, hPEPT1, stably transfected into chinese hamster ovary cells., Pharm. Res. 1996, 13, 1631-1634.

15. Lowry, O. H.; Rosebrough, N. J .; Farr, A. L.; Randall, R. J. Protein measurement with the Folin phenol reagent. J. Biol. Chem. 1951, 193, 265-275.

16. Walter, E.; J anich, S.; Roessler, B. J ; Hilfinger, J. M.; Amidon, G. L.; HT29-MTX/Caco-2 cocultures as an in vitro model for the intestinal epithelium: in vitro-in vivo correlation with permeability data from rats and humans. J . Pharm Sci. 1996, 85, 1070-1076.

17. De Lean, A.; Munson, P. J .; Rodbard, D. Simultaneous analysis of families of sigmoidgand assay and physiological dose-response curves. Am. J. Physiol. 1978, 235, E97-102.

18. Kramer, W.; Girbig, F.; Gutjaha, U.; Kleemann, H.-W.; Leipe I.; Urbach, H.; Wagner, A. Interaction of renin inhibitors with the intestinal uptake system for oligopeptides and betalactam antibiotics. Biochim. Biophys. Acta 1990, 1027, 2530.

19. Hu, M.; Subramanian, P.; Mosberg, H. I.; Amidon, G. L. Use of the peptide carrier system to improve the intestinal absorption of $L-\alpha$-methyldopa: carrier kinetics, intestinal permeabilities, and in vitro hydrolysis of dipeptidyl derivatives of L- $\alpha$-methyldopa. Pharm. Res. 1989, 6, 66-70.

20. Dantzig, A. H.; Bergin, L. Uptake of the cephalosporin, cephal exin, by a dipeptide transport carrier in the human intestinal cell line, Caco-2. Biochim. Biophays. Acta, 1990, 1027, 211-217.

21. Han, H-K.; de Vrueh, R. L. A.; Rhie, J . K.; Covitz, K.-M. Y.; Smith, P. L.; Lee, C.-P.; Oh, D.-M.; Sadée, W.: Amidon, G. L. 5'-Amino Acid Esters of Antiviral Nucleosides, Acyclovir and AZT, Are Absorbed by the Intestinal PEPT1 Peptide Transporter. Pharm. Res. 1998, 15(8), in press.

22. Mackenzie, B.; Loo, D. D. F.; Fei, Y.-J .; Liu, W.; Ganapathy, V.: Leibach, F. H.; Wright, E. M. Mechanisms of the human intestinal $\mathrm{H}^{+}$-coupled oligopeptide transporter hPEPT1. J . Biol. Chem. 1996, 271, 5430-5437.

23. Stenbaek, O., Myhre, E., Rugstad, H. E., Arnold, E.; Hansen, T. Pharmaco-kinetics of methyldopa in healthy man. Eur. J. Clin. Pharmacol. 1977, 12, 117-123.

24. Shindo, H.; Komai, T.; Kawai, K. Studies on the metabolism of $\mathrm{D}$ - and $\mathrm{L}$-isomers of 3,4-dihydroxyphenylalanine (DOPA). $\mathrm{V}$. Mechanism of intestinal absorption of $\mathrm{D}$ - and L-DOPA${ }^{14} \mathrm{C}$ in rats. Chem. Pharm. Bull. (Tokyo) 1973, 21, 20312038.

25. Shotwell, M. A.; J ayme, D. W.; Kilberg, M. S.; Oxender, D. L. Neutral amino acid transport systems in Chinese hamster ovary cells. J. Biol. Chem. 1981, 256, 5422-5427.

26. Friedman, D. I.; Amidon, G. L. Passive and carrier-mediated intestinal absorption components of two angiotensin converting enzyme (ACE) inhibitor prodrugs in rats: enalapril and fosinopril. Pharm. Res. 1989, 6, 1043-1047.

27. Sinko, P. J .; Amidon, G. L. Characterization of the oral absorption of $\beta$-lactam antibiotics. I. Cephalosporins: Determination of intrinsic membrane absorption parameters in the rat intestine in situ. Pharm. Res. 1988, 5, 645-650.

28. Oh, D.-M.; Sinko, P.J .; and Amidon, G. L., Characterization of the oral absorption of several aminopenicillins: Determination of intrinsic membrane absorption parameters in the rat intestine in situ. Int. J . Pharm. 1992, 85, 181-187.

\section{Acknowledgments}

We appreciate Dr. W. Sadée and Dr. K. M. Covitz (University of California, San Francisco) for providing the $\mathrm{CHO}-\mathrm{KI}$ and $\mathrm{CHO} /$ hPEPT1 cells. This work was supported by NIH/NIGM grant No. GM 37188 and a grant from Parke-Davis Pharmaceutical Research. 